\title{
Polyminimyoclonus in Hirayama disease
}

\author{
Dylan Meng, ${ }^{1}$ Kimia Ghavami, ${ }^{2}$ Tychicus Chen $\left({ }^{2}{ }^{2}\right.$
}

${ }^{1}$ Faculty of Medicine, University of British Columbia, Vancouver, British Columbia, Canada ${ }^{2}$ Division of Neurology, Faculty of Medicine, University of British Columbia, Vancouver, British Columbia, Canada

\section{Correspondence to Dr Tychicus Chen; tychicus@mail.ubc.ca}

Accepted 20 September 2021

\section{DESCRIPTION}

A 26-year-old man, right-handed, otherwise healthy warehouse worker presented with painless left-hand weakness. He noticed difficulty with fine finger movements and thumb articulation that had been gradually worsening over the past 2 years. He denied any sensory changes or involvement of any other muscles. There was no history of recent trauma, neck pain or bulbar symptoms. He had no regular medications. On examination, mental status and cranial nerve testing were unremarkable. Tone was normal. He had atrophy of the left first dorsal interosseus (FDI) and tremulous movements of the left digits with irregular jerky movements suggestive of polyminimyoclonus (video 1). Weakness in his left hand was measured by Medical Research Council grade: left FDI (4-/5), second palmar interosseus (3/5), abductor digiti minimi (4/5), flexor pollicis longus (FPL, $4-/ 5$ ) and abductor pollicis brevis $(4+/ 5)$; with normal strength in all other muscle groups. Right arm and leg strength, reflexes, sensation and gait were normal.

MRI of the cervical spine without contrast revealed left hemicord flattening between C5 and C7 without cord compression, with epidural venous distension on flexion view (figure 1), characteristic of Hirayama disease. Sensory and motor nerve conduction studies were unremarkable, whereas electromyography showed chronic neurogenic changes in the left FPL, flexor digitorum profundus (median) and FDI muscles. $\mathrm{He}$ was treated conservatively with soft collar and had no progression of weakness at 6-month follow-up.

Hirayama disease, or monomelic amyotrophy, is an uncommon cause of distal arm weakness, clinically distinct from other motor neuron diseases as it has a benign prognosis. ${ }^{1}$ It primarily

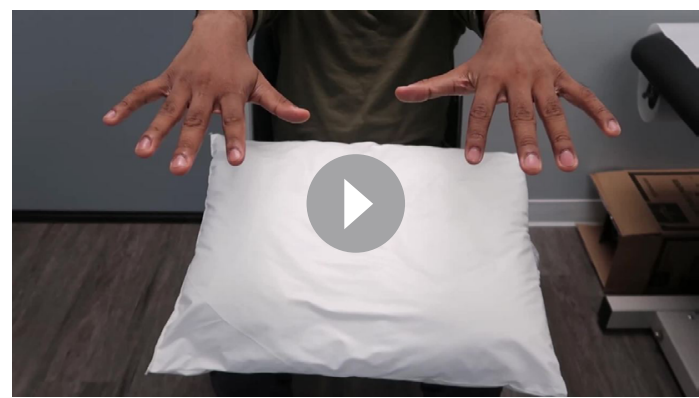

Video 1 Polyminimyoclonus of the left thumb and second digit elicited by outstretching the arms and fully extending the fingers. A second recording demonstrates polyminimyoclonus of the left second to fourth digits in the same position, extinguished at rest.

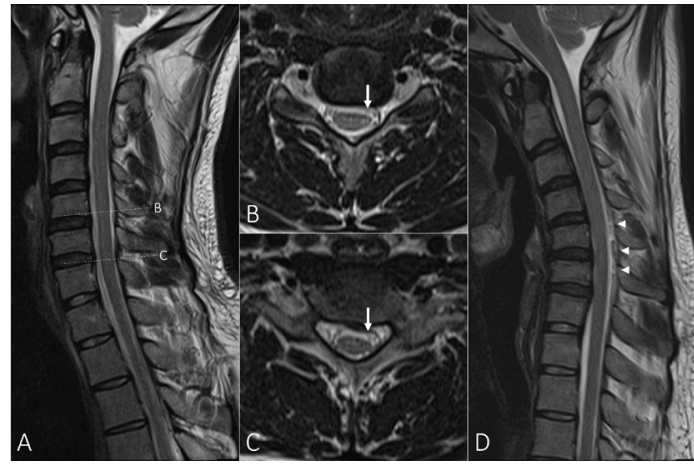

Figure 1 T2-Weighted MRI cervical spine. (A) Sagittal and $(B, C)$ axial views demonstrating subtle abnormal cord signal and left hemicord flattening (arrows) at the levels of C5-C7. (D) Sagittal flexion view demonstrating enlarged epidural space with multiple flow voids (arrowheads) at these levels.

affects adolescents with male predominance. ${ }^{1}$ It is characterised by progressive distal upper extremity weakness and atrophy in the C7-T1 distribution, followed by spontaneous arrest of disease progression. ${ }^{1}$ The majority of cases begin unilaterally progressing to asymmetric bilateral involvement. ${ }^{1}$ Cold paresis and polyminimyoclonus are widely observed. ${ }^{2} 3$ MRI of the cervical spine may show subtle or no findings, but when performed in neck flexion classically shows anterior displacement of the posterior dura, enlarged epidural spaces with flow voids, flattening of the cervical cord with or without signal change and an enhancing crescentic-shaped mass in the posterior epidural space. ${ }^{24}$ Unlike other motor neuron diseases, the majority of cases stabilise within 5-6 years. $^{23}$

Polyminimyoclonus is defined as intermittent, low-amplitude, arrhythmic movements most

\section{Learning points}

- Hirayama disease should be suspected in young males presenting with progressive weakness of the upper extremities, especially when polyminimyoclonus is seen.

- Polyminimyoclonus should be distinguished from tremor, and when seen may be a clue toward a diagnosis of Hirayama disease or other conditions associated with anterior horn cell disruption.

- Investigation of Hirayama disease should include MRI in neck flexion, as the expected findings may not be present in neutral position, and establishes the diagnosis. 
commonly seen in the hands and fingers. ${ }^{5}$ The movements are accentuated when the hands are outstretched, fingers are extended or during action. ${ }^{5}$ It has been proposed that polyminimyoclonus associated with anterior horn cell disruption, such as in Hirayama disease, is a result of fasciculations occurring so frequently that it gives the appearance of myoclonic movement. ${ }^{6}$ This sign is one of the clinical hallmarks of Hirayama disease and has been reported in 61\%-80\% of cases. $^{23}$ It should not be mistaken for tremor and when seen may be a clue towards a diagnosis of Hirayama disease as in this case.

Acknowledgements The authors wish to thank the patient for allowing us to publish this case report.

Contributors All authors contributed substantially to the conception of the article, the drafting of the manuscript, critical revision and have approved the final version for submission. All authors are accountable for any and all aspects of the work detailed in the submitted article.Contributor statement: DM: drafting the original manuscript, performing literature review and revising the article for intellectual content. KG: drafting the original manuscript and revising the article for intellectual content. TC: conceptualisation of the manuscript and revising the article for intellectual content.
Funding The authors have not declared a specific grant for this research from any funding agency in the public, commercial or not-for-profit sectors.

Competing interests None declared.

Patient consent for publication Consent obtained directly from patient(s).

Provenance and peer review Not commissioned; externally peer reviewed.

\section{ORCID iD}

Tychicus Chen http://orcid.org/0000-0003-2146-9572

\section{REFERENCES}

1 Huang Y-L, Chen C-J. Hirayama disease. Neuroimaging Clin N Am 2011;21:939-50.

2 Zhou B, Chen L, Fan D, et al. Clinical features of Hirayama disease in mainland China. Amyotroph Lateral Scler 2010;11:133-9.

3 Tashiro K, Kikuchi S, Itoyama Y, et al. Nationwide survey of juvenile muscular atrophy of distal upper extremity (Hirayama disease) in Japan. Amyotroph Lateral Scler 2006:7:38-45.

4 Al-Hashel JY, Abdelnabi EA, Ibrahim Ismail I. Monomelic amyotrophy (Hirayama disease): a rare case report and literature review. Case Rep Neurol 2020;12:291-8.

5 Ganguly J, Chai JR, Jog M. Minipolymyoclonus: a critical appraisal. J Mov Disord 2021;14:114-8.

6 Bhat S, Ma W, Kozochonok E, et al. Fasciculations masquerading as minipolymyoclonus in bulbospinal muscular atrophy. Ann Indian Acad Neurol 2015;18:249-51.

Copyright 2021 BMJ Publishing Group. All rights reserved. For permission to reuse any of this content visit

https://www.bmj.com/company/products-services/rights-and-licensing/permissions/

BMJ Case Report Fellows may re-use this article for personal use and teaching without any further permission.

Become a Fellow of BMJ Case Reports today and you can:

- Submit as many cases as you like

- Enjoy fast sympathetic peer review and rapid publication of accepted articles

- Access all the published articles

Re-use any of the published material for personal use and teaching without further permission

Customer Service

If you have any further queries about your subscription, please contact our customer services team on +44 (0) 2071111105 or via email at support@bmj.com.

Visit casereports.bmj.com for more articles like this and to become a Fellow 